Article

\title{
The Influence of Fluorination on Nano-Scale Phase Separation and Photovoltaic Performance of Small Molecular/PC ${ }_{71}$ BM Blends
}

\author{
Zhen Lu ${ }^{1}$, Wen Liu ${ }^{1}$, Jingjing Li $^{1}$, Tao Fang ${ }^{2}$, Wanning Li ${ }^{1}$, Jicheng Zhang ${ }^{2}$, Feng Feng ${ }^{1, *}$ and \\ Wenhua Li ${ }^{2, *}$ \\ 1 College of Chemistry and Environmental Engineering, ShanXi DaTong University, Datong 037009, China; \\ luzhen0313@aliyun.com (Z.L.); liuwen19701021@163.com (W.L.); lijingjing8150@163.com (J.L.); \\ liwanning2016@163.com (W.L.) \\ 2 Beijing Key Laboratory of Energy Conversion and Storage Materials, College of Chemistry, \\ Beijing Normal University, Beijing 100875, China; fangtao@bnu.edu.cn (T.F.); \\ zhangjichengbnu@hotmail.com (J.Z.) \\ * Correspondence: feng-feng64@263.net (F.F.); liwenhua@bnu.edu.cn (W.L.); \\ Tel.: +86-0352-6090018 (F.F.); +86-010-62207699 (W.L.)
}

Academic Editor: Guanying Chen

Received: 5 February 2016; Accepted: 11 April 2016; Published: 22 April 2016

\begin{abstract}
To investigate the fluorination influence on the photovoltaic performance of small molecular based organic solar cells (OSCs), six small molecules based on 2,1,3-benzothiadiazole (BT), and diketopyrrolopyrrole (DPP) as core and fluorinated phenyl (DFP) and triphenyl amine (TPA) as different terminal units (DFP-BT-DFP, DFP-BT-TPA, TPA-BT-TPA, DFP-DPP-DFP, DFP-DPP-TPA, and TPA-DPP-TPA) were synthesized. With one or two fluorinated phenyl as the end group(s), HOMO level of BT and DPP based small molecular donors were gradually decreased, inducing high open circuit voltage for fluorinated phenyl based OSCs. DFP-BT-TPA and DFP-DPP-TPA based blend films both displayed stronger nano-scale aggregation in comparison to TPA-BT-TPA and TPA-DPP-TPA, respectively, which would also lead to higher hole motilities in devices. Ultimately, improved power conversion efficiency (PCE) of $2.17 \%$ and $1.22 \%$ was acquired for DFP-BT-TPA and DFP-DPP-TPA based devices, respectively. These results demonstrated that the nano-scale aggregation size of small molecules in photovoltaic devices could be significantly enhanced by introducing a fluorine atom at the donor unit of small molecules, which will provide understanding about the relationship of chemical structure and nano-scale phase separation in OSCs.
\end{abstract}

Keywords: small molecule; fluorinated phenyl (DFP) groups; organic solar cell; solution process; nanoscale phase separation

\section{Introduction}

Recently, organic solar cells (OSCs) have received great attention due to their advantages of solution processability, light weight, low cost, and flexibility [1-4]. Generally, bulk-heterojunction architecture was adopted with the electron-efficient conjugated polymer or small molecule as the donor and electron-deficient fullerene derivative such as $(6,6)$-phenyl- $C_{71}$-butyric acid methyl ester $\left(\mathrm{PC}_{71} \mathrm{BM}\right)$ as the acceptor [5-7]. In comparison to widely investigated polymeric counterparts, small molecule-based OSCs have distinct advantages of well-defined chemical structures, easy purification, and high purity without batch-to-batch variation $[5,6,8,9]$. Therefore, small molecule-based materials are more suitable for mass production compared to polymer based ones. Driven by the developing of high efficiency small molecular donors and the investigation of nano-scale phase separation at 
donor/acceptor interfaces, power conversion efficiency (PCE) of nearly 10\% for small molecule-based single-junction OSCs has been achieved [10,11].

Due to the strong electron-withdrawing capability, the introducing of fluorine atoms onto the conjugated backbones of small molecules could reduce the HOMO energy levels, resulting in higher open circuit voltage $\left(V_{\mathrm{oc}}\right)$ in OSCs [12-19]. Furthermore, the intra-molecular interaction of F-S and F-H could also induce closed packing properties and lead to superior hole mobiles [17,20-22]. Fluorinated molecules also showed good thermal and electrochemical stability, which would be helpful in the future commercial application. Although fluorinated small molecules have been broadly studied, fluorine atoms were mostly introduced to the acceptor unit of donor materials $[18,19,23-25]$, works focus on the investigation of small molecules with a fluorine atom at the donor unit were still rare. Triphenylamine (TPA) based small molecules were common donor materials in organic semiconductor devices [8,26-30]. Nevertheless, the inferior planarity of TPA unit would induce weak intramolecular packing of small molecules and lead to a relatively low hole mobility in OSCs [31-33]. Conjugating a fluorine unit could therefore enhance the aggregation of TPA based small molecules and result in an appropriate nano-scale phase separation when blended with $\mathrm{PC}_{71} \mathrm{BM}$. As a result, higher hole motilities and PCE were expected.

In this contribution, six small molecules (DFP-BT-DFP, DFP-BT-TPA, TPA-BT-TPA, DFP-DPP-DFP, DFP-DPP-TPA, and TPA-DPP-TPA) based on 2,1,3-benzothiadiazole (BT) or diketopyrrolopyrrole (DPP) (Chart 1) as the core and TPA or fluorinated phenyl (DFP) groups as the flanks were synthesized and applied as the donors in OSCs [34-36]. BT or DPP groups were chosen as the acceptor units due to their uniquely planarity and remarkably electron-withdrawing capabilities, and various DFP groups were conjugated as the end groups to investigate the influence of fluorinated donor unit on the performance of small molecule based OSCs. With one or two DFP as the end group(s), the HOMO level of BT-based small molecular donors TPA-BT-TPA, DFP-BT-TPA, and DFP-BT-DFP were gradually decreased; DPP-based small molecular donors also exhibited similar tendency, which would be beneficial to achieve high $V_{\mathrm{Oc}}$ in OSCs. Due to the inferior solubility of DFP-BT-DFP and DFP-DPP-DFP, only TPA-BT-TPA, TPA-DPP-TPA, DFP-BT-TPA, and DFP-DPP-TPA were used as donor materials in OSCs. DFP-BT-TPA and DFP-DPP-TPA based blend films both displayed stronger nano-scale aggregation in comparison to TPA-BT-TPA and TPA-DPP-TPA, respectively, leading to higher hole motilities in devices. Ultimately, a PCE of $2.17 \%$ with a $V_{\text {oc }}$ of $0.90 \mathrm{~V}$ and a PCE of $1.22 \%$ with a $V_{\text {oc }}$ of $0.78 \mathrm{~V}$ was acquired for DFP-BT-TPA and DFP-DPP-TPA-based devices, respectively. Our results demonstrated that the nano-scale aggregation size of small molecules in photovoltaic devices could be significantly enhanced by introducing a fluorine atom at the donor unit of small molecules, which provided useful information in the further design of high efficiency small molecular donors for OSCs.

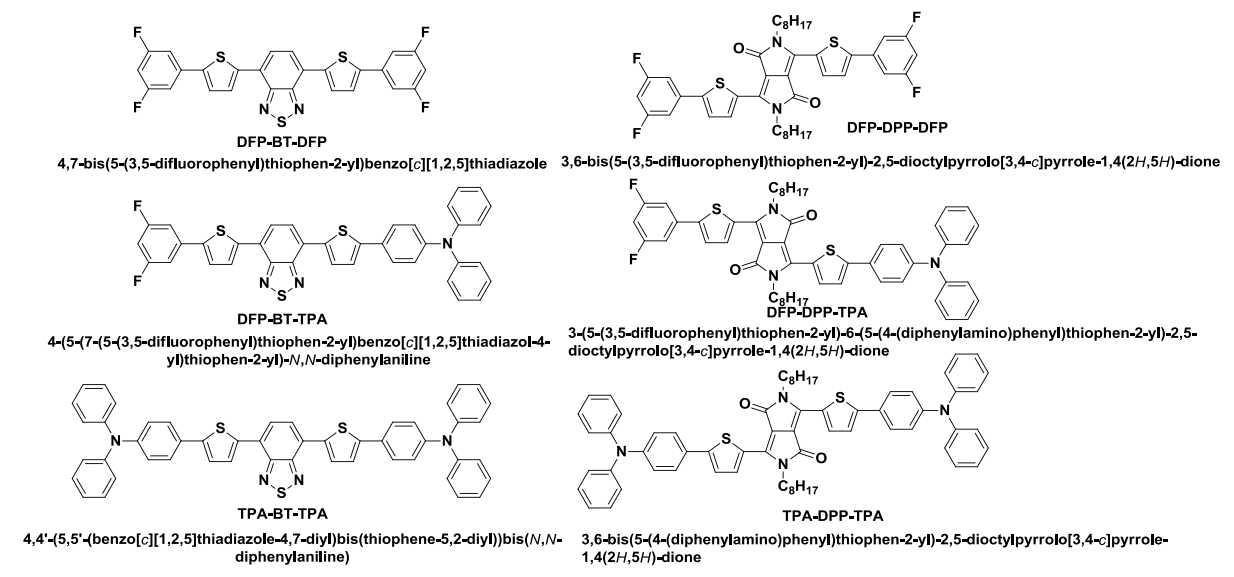

Chart 1. Chemical structures of small molecules (DFP-BT-DFP, DFP-BT-TPA, TPA-BT-TPA, DFP-DPP-DFP, DFP-DPP-TPA, and TPA-DPP-TPA). DFP: fluorinated phenyl; BT: 2,1,3-benzothiadiazole; DPP: diketopyrrolopyrrole; TPA: triphenyl amine. 


\section{Results and discussions}

\subsection{Synthesis}

The synthesis route of six small molecules (DFP-BT-DFP, DFP-BT-TPA, TPA-BT-TPA, DFP-DPP-DFP, DFP-DPP-TPA, and TPA-DPP-TPA) is outlined in Scheme 1. All small molecules were synthesized by using the Suzuki cross-coupling reaction between a boronic acid ester and a brominated aromatic compound in toluene and $\mathrm{K}_{2} \mathrm{CO}_{3}$ aqueous solution under $\mathrm{N}_{2}$ with $\mathrm{Pd}\left(\mathrm{PPh}_{3}\right)_{4}$ as the catalyst procedure. DFP-BT-TPA, TPA-BT-TPA, DFP-DPP-TPA, and TPA-DPP-TPA show good solubility in common organic solvents such as chloroform $\left(\mathrm{CHCl}_{3}\right)$, tetrahydrofuran (THF), and chlorobenzene (CB). However, DFP-BT-DFP and DFP-DPP-DFP showed poor solubility in these solvents, which might be ascribed to the fluorinated and symmetric molecular structure. As shown in Figure S1, DSC images demonstrated that all these small molecules were crystalline, which might be beneficial for the closed packing properties when blended with $\mathrm{PC}_{71} \mathrm{BM}$. As shown in Figure S2 and Table 1, DFP-BT-DFP, DFP-BT-TPA, TPA-BT-TPA, DFP-DPP-DFP, DFP-DPP-TPA, and TPA-DPP-TPA all exhibited good thermal stability with a $5 \%$ weight loss of $350,450,461,374,400$, and $408{ }^{\circ} \mathrm{C}$, respectively. Our results revealed TPA-based small molecules possess better thermal stability than DFP based small molecules, which is beyond our expectation. The $5 \%$ weight loss temperature of DFP-BT-TPA and TPA-BT-TPA could reach to around $450{ }^{\circ} \mathrm{C}$, making them very stable in the application of OSCs.

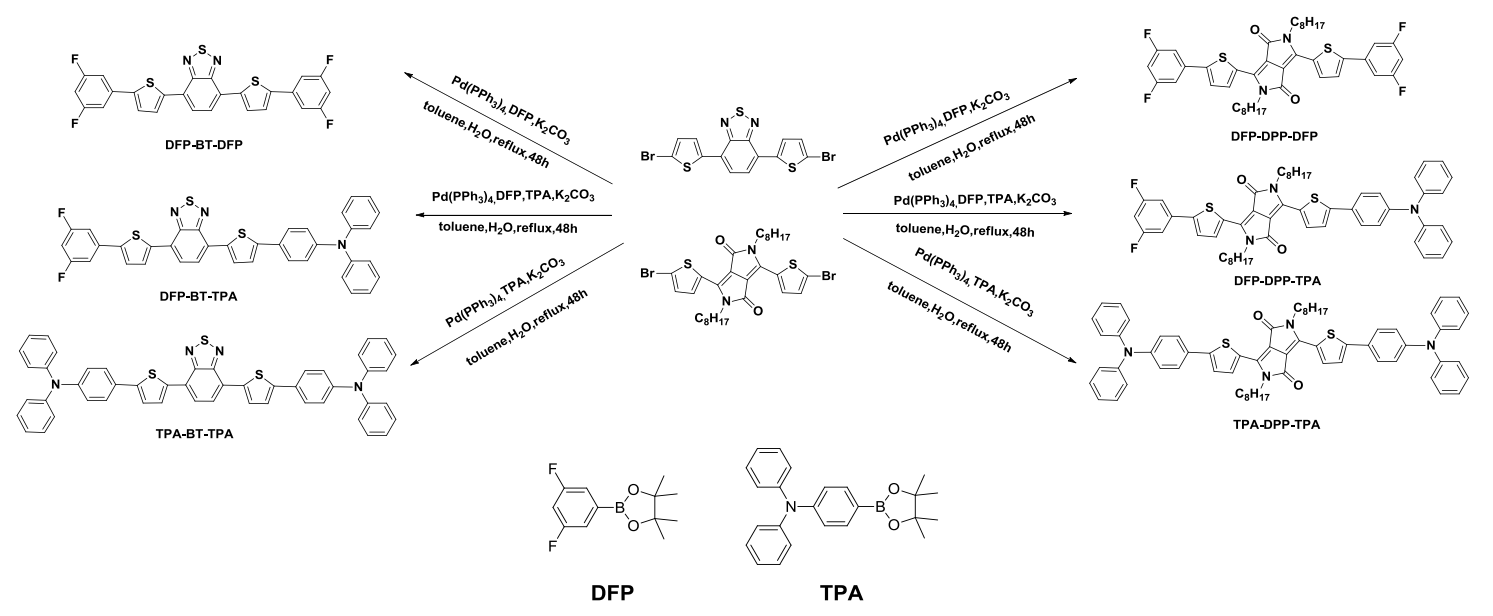

Scheme 1. Synthetic route of six small molecules (DFP-BT-DFP, DFP-BT-TPA, TPA-BT-TPA, DFP-DPP-DFP, DFP-DPP-TPA, and TPA-DPP-TPA).

Table 1. Optical, electrochemical, and physical properties of small molecules.

\begin{tabular}{|c|c|c|c|c|c|c|c|c|}
\hline Donor & $\begin{array}{c}\lambda_{\text {abs }}(\mathrm{S}) \\
(\mathrm{nm})^{\mathrm{a}}\end{array}$ & $\begin{array}{l}\lambda_{\mathrm{abs}}(\mathrm{F}) \\
(\mathrm{nm})^{b}\end{array}$ & $\begin{array}{c}\lambda_{\text {onset }} \\
(\mathrm{nm})\end{array}$ & $E_{\mathrm{g}, \mathrm{opt}}(\mathrm{ev})$ & $\mathrm{HOMO}^{\mathrm{c}}$ & LUMO $^{d}$ & $T_{\mathrm{m}}\left({ }^{\circ} \mathrm{C}\right)$ & $T_{\mathrm{g}}\left({ }^{\circ} \mathrm{C}\right)$ \\
\hline DFP-BT-DFP & 488 & 505 & 636 & 1.95 & -5.73 & -3.78 & 246.6 & 350 \\
\hline DFP-BT-TPA & 525 & 530 & 643 & 1.93 & -5.34 & -3.41 & 248.8 & 450 \\
\hline TPA-BT-TPA & 544 & 547 & 659 & 1.88 & -5.17 & -3.29 & 254.4 & 461 \\
\hline DFP-DPP-DFP & 598 & 616,663 & 715 & 1.73 & -5.59 & -3.86 & 216.9 & 374 \\
\hline DFP-DPP-TPA & 619 & 583,627 & 746 & 1.66 & -5.13 & -3.47 & 195.3 & 400 \\
\hline TPA-DPP-TPA & 634 & 588,656 & 760 & 1.63 & -5.07 & -3.44 & 217.3 & 408 \\
\hline
\end{tabular}

\subsection{Optical Properties}

The normalized ultraviolet-visible spectroscopy (UV-VIS) absorption spectra of six small molecules in dilute $\mathrm{CB}$ solution and as thin films at $25{ }^{\circ} \mathrm{C}$ are shown in Figure 1 . These small 
molecules exhibit a broad absorption in the range from 300 to $700 \mathrm{~nm}$ with two distinguishable absorption bands, which could be attributed to the $\pi-\pi^{*}$ transition and the internal charge transfer (ICT) interaction between the donor and the acceptor units $[4,21,28]$. Upon going from solution to the solid state, the absorption spectra become broader and redshift $17 \mathrm{~nm}$ for DFP-BT-DFP, $5 \mathrm{~nm}$ for DFP-BT-TPA, and $5 \mathrm{~nm}$ for TPA-BT-TPA, respectively, which can be attributed to the closer $\pi-\pi$ stacking in solid state. The onsets of film absorption spectra are 636, 643, and $659 \mathrm{~nm}$, respectively, for these small molecules, and optical band gaps $\left(E_{\mathrm{g}}\right.$, opt $)$ were calculated to be 1.95, 1.93, and $1.88 \mathrm{eV}$, respectively. Similar to BT based small molecules, DFP-DPP-DFP, DFP-DPP-TPA, TPA-DPP-TPA show broader absorption over the range from 300 to $750 \mathrm{~nm}$ with two distinguishable absorption bands. Specifically, the absorption for DFP-DPP-DFP showed stronger shoulder peaks, revealing more ordered molecular stacking capabilities in the solid state [37,38]. From the absorption onsets, the optical band gaps were estimated to be 1.73, 1.66, and $1.63 \mathrm{eV}$ for DFP-DPP-DFP, DFP-DPP-TPA, and TAP-DPP-TPA, respectively.
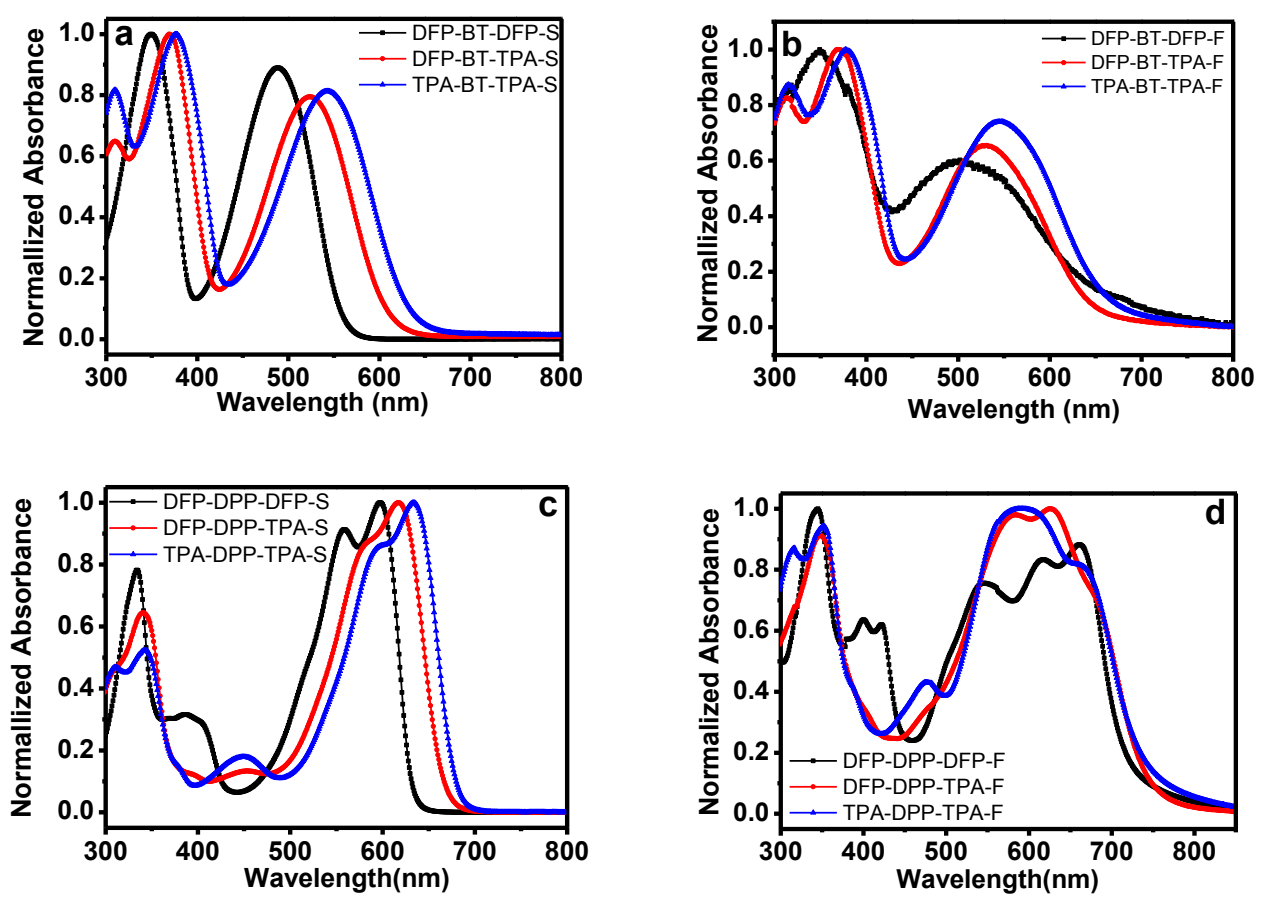

Figure 1. Normalized ultraviolet-visible spectroscopy (UV-VIS) absorption spectra of the six small molecules. $(\mathbf{a}, \mathbf{c})$ in dilute chlorobenzene $(\mathrm{CB})$ solution; $(\mathbf{b}, \mathbf{d})$ as thin film on a quartz substrate.

\subsection{Cyclic Voltammetry}

Cyclic voltammetry (CV) experiments were carried out to evaluate electrochemical characteristics of these small molecules. As shown in Figure 2, the onset oxidation potentials $\left(E_{\mathrm{ox}}\right)$ were 1.02, 0.63, $0.46 \mathrm{~V}$ for DFP-BT-DFP, DFP-BT-TPA, and TPA-BT-TPA, respectively, According to the equation $E_{\mathrm{HOMO}}=-\left(4.71+E_{\mathrm{OX}}\right)(\mathrm{eV})$, highest occupied molecular orbital (HOMO) energy levels of these small molecules could be determined to be $-5.73,-5.34$, and $-5.17 \mathrm{eV}$. With the combination of the optical band gap and the equation $E_{\mathrm{LUMO}}=E_{\mathrm{HOMO}}+E_{\mathrm{g} \text {, opt }}$, [39] the lowest unoccupied molecular orbital (LUMO) energy levels were calculated to be $-3.78,-3.41$, and $-3.29 \mathrm{eV}$ for DFP-BT-DFP, DFP-BT-TPA, and TPA-BT-TPA, respectively. Similarly, the HOMO and LUMO energy levels were determined to be $-5.59,-5.13,-5.07$ and $-3.86,-3.47,-3.44$ eV for DFP-DPP-DFP, DFP-DPP-TPA, and TAP-DPP-TPA, respectively. These results demonstrated that the incorporation of fluorine atom could significantly decrease the HOMO energy levels of small molecules, which would be beneficial to achieve high $V_{\mathrm{oc}}$ in OSCs. The data are also summarized in Table 1. 

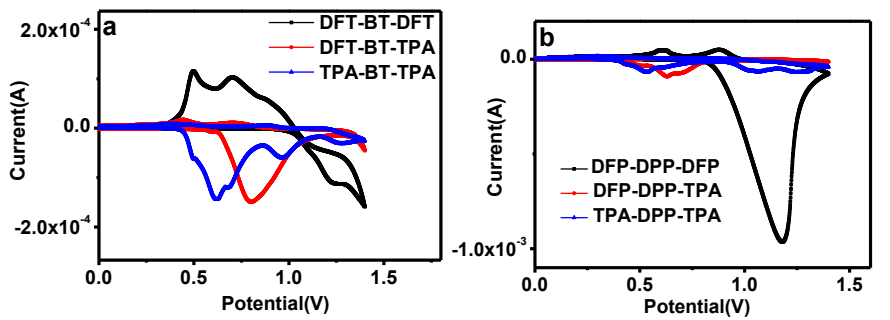

Figure 2. Cyclic voltammograms of small molecules. (a) DFP-BT-DFP, DFP-BT-TPA, TPA-BT-TPA; and (b) DFP-DPP-DFP, DFP-DPP-TPA, TPA-DPP-TPA.

\subsection{Photovoltaic Properties}

Photovoltaic properties of these small molecules were investigated by a general device structure of indium tin oxides (ITO)/poly(3,4-ethylenedioxythiophene):poly(styrenesulfonate) (PEDOT:PSS)/donor:PC ${ }_{71} \mathrm{BM} / \mathrm{LiF} / \mathrm{Al}$. Different spin-coating speeds and weight ratios of small molecules to $\mathrm{PC}_{71} \mathrm{BM}$ in a $\mathrm{CB}$ solution were screened to optimize the photovoltaic performance. Due to the inferior solubility of DFP-BT-DFP and DFP-DPP-DFP, typical cluster structures with boosted big domains could be easily observed by naked eyes. As a result, photovoltaic performance of these two small molecules based devices would not be discussed. For other small molecules, the current density-voltage $(J-V)$ curves are shown in Figure 3a and device characteristics are summarized in Table 2. After optimization, superior PCE values could be achieved with a weight ratio of 1:4 (w/w) for all devices, and a PCE of $1.95 \%$ with a $V_{\text {oc }}$ of $0.82 \mathrm{~V}, J_{\mathrm{sc}}$ of $5.97 \mathrm{~mA} \cdot \mathrm{cm}^{-2}$ and fill factor (FF) of 0.40 was achieved for TPA-BT-TPA devices. When one TPA unit was replaced by one DFP group, increased $V_{\text {oc }}$ of $0.90 \mathrm{~V}$ and $J_{\mathrm{sc}}$ of $6.12 \mathrm{~mA} \cdot \mathrm{cm}^{-2}$ were obtained for DFP-BT-TPA based device, leading to higher PCE of $2.17 \%$. Similarly, DFP-DPP-TPA based solar cells exhibited a higher PCE of $1.22 \%$ with a $V_{\mathrm{oc}}$ of $0.78 \mathrm{~V}$ than that of TPA-DPP-TPA based devices. This improvement could be attributed to the increase of $V_{\mathrm{oc}}$ and $J_{\mathrm{sc}}$. Since $V_{\mathrm{oc}}$ is related to the offset between HOMO level of donor materials and LUMO level of $\mathrm{PC}_{71} \mathrm{BM}$, the decrease of HOMO levels for DFP based small molecules would lead to higher $V_{\mathrm{oc}}$ [3]. Meanwhile, DFP based small molecules also possesses bigger nano-scale aggregates, and resulting higher hole mobilities in the active layer (vide infra), which would also lead to higher $J_{\mathrm{sc}}$ in devices.
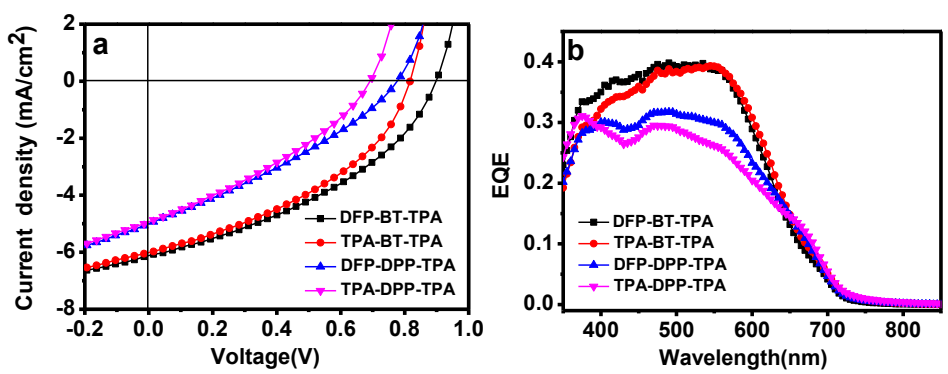

Figure 3. $J-V$ characteristics (a) and external quantum efficiencie (EQE) curves (b) of devices fabricated from the blend of small molecule: $\mathrm{PC}_{71} \mathrm{BM}$.

Table 2. Photovoltaic performance and hole mobilities of small molecule-based devices. FF: fill factor; PCE: power conversion efficiency; SCLC: space charge limited current.

\begin{tabular}{|c|c|c|c|c|c|c|}
\hline Donor Molecule & $V_{\text {oc }}(\mathrm{V})$ & $J_{\mathrm{sc}}\left(\mathrm{mA} \cdot \mathrm{cm}^{-2}\right)$ & FF & PCE (max/ave) ${ }^{a}(\%)$ & Thickness (nm) & $\operatorname{SCLC}\left(\mathrm{cm}^{2} \cdot \mathrm{V}^{-1} \cdot \mathrm{s}^{-1}\right)$ \\
\hline DFP-BT-TPA & 0.90 & 6.12 & 0.39 & $2.17 / 2.08$ & 76 & $3.81 \times 10^{-4}$ \\
\hline TPA-BT-TPA & 0.82 & 5.97 & 0.40 & $1.95 / 1.85$ & 82 & $4.42 \times 10^{-5}$ \\
\hline DFP-DPP-TPA & 0.78 & 4.95 & 0.32 & $1.22 / 1.17$ & 70 & $9.35 \times 10^{-5}$ \\
\hline TPA-DPP-TPA & 0.70 & 4.90 & 0.34 & $1.15 / 1.02$ & 85 & $3.26 \times 10^{-5}$ \\
\hline
\end{tabular}

${ }^{\text {a }}$ Average value recorded over 20 devices. 
To verify the $J_{\mathrm{sc}}$ obtained from $J-V$ measurement, the external quantum efficiencies (EQEs) of devices were measured. As shown in Figure 3b, the EQE images of devices all displayed a broad response in the range from 350 to $600 \mathrm{~nm}$, and the maximum EQE value of DFP-BT-TPA and TPA-BT-TPA-based devices are both $40 \%$, which are higher than that of DFP-DPP-TPA and TPA-DPP-TPA. $J_{\mathrm{SC}}$ values integrated from EQE curves all agreed approximately with that obtained from $J-V$ measurement.

The hole mobilities of these devices were measured by the space charge limited current (SCLC) method. Hole-only devices were fabricated with a structure of ITO/PEDOT:PSS/donor:PC 71 BM/Au and resulting hole mobility value $(\mu)$ was calculated from the dark $J-V$ experiments. Dark $J$ - $V$ curves were fitted by using the Mott-Gurney equation: $J=9 \varepsilon_{\mathrm{o}} \varepsilon_{\mathrm{r}} \mu V^{2} / 8 \mathrm{~L}^{3}$, where $\mathrm{J}$ is the space charge limited current, $\varepsilon_{\mathrm{O}}$ is the vacuum permittivity, $\varepsilon_{\mathrm{r}}$ is the permittivity of the active layer, $\mu$ is the hole mobility of small molecules, and L is the thickness of the active layer. $\mu$ of devices based on DFP-BT-TPA and DFP-DPP-TPA were evaluated to be $3.81 \times 10^{-4}$ and $9.35 \times 10^{-5} \mathrm{~cm}^{2} \cdot \mathrm{V}^{-1} \cdot \mathrm{s}^{-1}$, respectively, and $\mu$ of TPA-BT-TPA and TPA-DPP-TPA based devices were determined to be $4.42 \times 10^{-5}$ and $3.26 \times 10^{-5} \mathrm{~cm}^{2} \cdot \mathrm{V}^{-1} \cdot \mathrm{s}^{-1}$, respectively. $\mu$ of DFP based devices were obviously higher than that of TPA based ones, which might be attributed to their planar chemical structure and resulting bigger nano-scale aggregation in the blend films.

\subsection{Film Morphology}

Atomic force microscopy (AFM) experiments were carried out to investigate the surface morphology of the active layer. Well-mixed blend films were in favor of exciton dissociation in devices, whereas appropriate nano-scale aggregation of small molecules was also important for the charge transport. Therefore, suitable nano-scale phase separation is critical to obtain a superior photovoltaic performance $[40,41]$. As shown in Figure 4, blend films based on TPA-BT-TPA and TPA-DPP-TPA were both uniform and smooth with a root-mean-square (RMS) roughness value of 0.78 and $0.65 \mathrm{~nm}$, which might be ascribed to the inferior packing properties of TPA group. For devices based on DFP-BT-TPA and DFP-DPP-TPA, rougher blend film surface with a RMS roughness value of $2.35 \mathrm{~nm}$ and $0.84 \mathrm{~nm}$ were acquired, demonstrating the domain size of DFP-BT-TPA and DFP-DPP-TPA were higher than TPA-BT-TPA and TPA-DPP-TPA in devices. Our results demonstrated that incorporating a DFT group as the end groups could enhance the nano-scale aggregation in the devices, which would be beneficial to the charge transport in the blend films, and lead to higher $J_{\mathrm{sc}}$ and PCE.

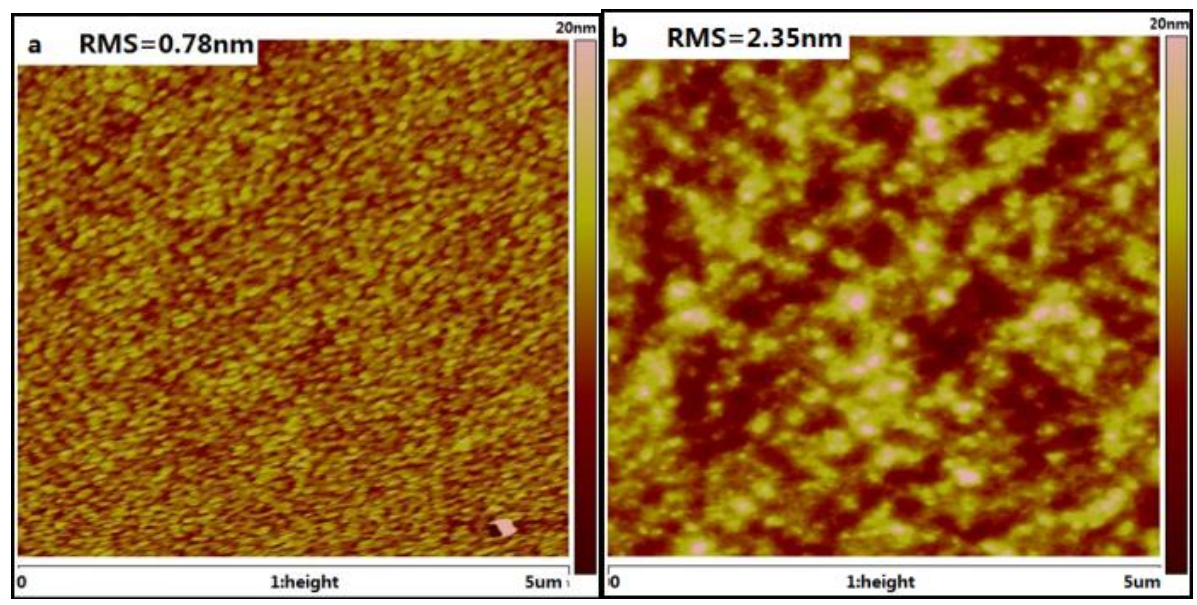

Figure 4. Cont. 


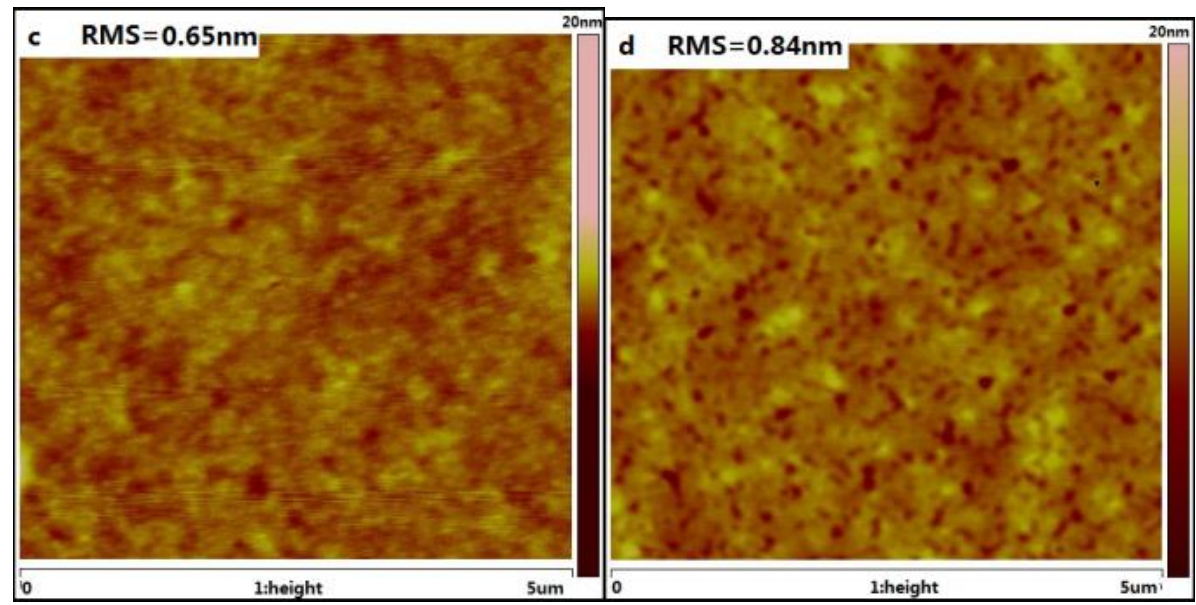

Figure 4. Atomic force microscopy (AFM) $\left(5 \times 5 \mu \mathrm{m}^{2}\right)$ height images of blend films. (a) TPA-BT-TPA:PC ${ }_{71}$ BM; (b) DFP-BT-TPA:PC 71 BM; (c) TPA-DPP-TPA:PC 71 BM; and (d) DFP-DPP-TPA:PC 71 BM.

\section{Experimental Section}

\subsection{Materials}

All chemicals were purchased from commercial sources and used without further purification, and all solvents were purified by standard techniques. Additionally, all reactions were carried out under the nitrogen atmosphere unless otherwise stated. The catalyst procedure $\mathrm{Pd}\left(\mathrm{PPh}_{3}\right)_{4}$ [34], 4,7-bis(5-bromothiophen-2-yl)benzo[c][1,2,5]thiadiazole [35] and 3,6-bis(5-bromothiophen-2-yl)-2,5dioctylpyrrolo[3,4-c]pyrrole-1,4-dione [36] were synthesized according to the literature procedures.

\subsection{Measurements and Characterization}

All reactions were monitored by thin layer chromatography (TLC) on silica gel 60 F254 (Merck, Beijing, China, $0.2 \mathrm{~mm}$ ), and column chromatography was performed on silica gel (200 300 mesh). ${ }^{1} \mathrm{H}$ and ${ }^{13} \mathrm{C}$ NMR spectra were recorded on a Bruker AV 400 spectrometer (Saarbrücken, Germany) using $\mathrm{CDCl}_{3}$ as the solvents. Differential scanning calorimetry (DSC) measurements were performed on the Perkin-Elmer Diamond DSC instrument (Shanghai, China) under a nitrogen atmosphere with a heating rate of $20^{\circ} \mathrm{C} / \mathrm{min}$. UV-VIS absorption spectra was recorded on the PerkinElmer UV-VIS spectrometer model Lambda 750 (Shanghai, China). The electrochemical behavior of small molecules was achieved using $\mathrm{CHI}$ 630A electrochemical analyzer (Beijing, China) with a standard three-electrode electrochemical cell in $0.1 \mathrm{M} \mathrm{Bu}_{4} \mathrm{NPF}_{6}$ in $\mathrm{CH}_{3} \mathrm{CN}$ solution. A glassy carbon working electrode, a Pt wire counter electrode, and an $\mathrm{Ag} / \mathrm{AgNO}_{3}\left(0.01 \mathrm{M}\right.$ in $\left.\mathrm{CH}_{3} \mathrm{CN}\right)$ reference electrode were used. Elemental analyses were performed on a Flash EA 1112 analyzer (Lakewood, CO, USA), and atomic force microscopy (AFM) measurements were carried out in the tapping mode using a Digital Instrument Multimode Nanoscope IIIA (Plainview, TX, USA). The thickness of the active layers was determined by the Dektak $6 \mathrm{M}$ surface profilometer (Beijing, China).

\subsection{Fabrication and Characterization of SCLC}

Devices used to measure the space charge limited current (SCLC) were fabricated with a configuration of ITO/PEDOT:PSS/small molecule:PC ${ }_{71} \mathrm{BM} / \mathrm{Au}$. The conductivity of ITO was $20 \Omega$. PEDOT:PSS is Baytron Al 4083 from H.C.Starck (Leverkusen, Germany) and filtered with a $0.45 \mu \mathrm{m}$ polyethersulfone (PES) film before use. The PEDOT:PSS was spin-coated on top of a ITO substrate from a speed of $3000 \mathrm{rpm} / \mathrm{s}$ for $60 \mathrm{~s}$ and dried at $130{ }^{\circ} \mathrm{C}$ for $15 \mathrm{~min}$ on a hotplate. The thickness of the PEDOT:PSS layer was about $40 \mathrm{~nm}$. Small molecule and $\mathrm{PC}_{71} \mathrm{BM}$ was dissolved in chlorobenzene (CB) at $110{ }^{\circ} \mathrm{C}$ overnight, and then spin-coated onto the PEDOT:PSS layer. The top electrode was 
subsequently thermally evaporated with a $100 \mathrm{~nm}$ of gold under a pressure of $10^{-4} \mathrm{~Pa}$ by a shadow mask. Dark current-voltage characteristics were recorded using an Agilent B2902A Source (Taiwan) under darkness in a range of $0 \mathrm{~V}$ to $5.0 \mathrm{~V}$.

\subsection{Fabrication and Characterization of PSCS}

PSCs were fabricated with the device configuration of ITO/PEDOT:PSS/small molecule:PC ${ }_{71} \mathrm{BM} / \mathrm{LiF} / \mathrm{Al}$. ITO glasses with a conductivity of $20 \Omega$ were cleaned before use. PEDOT:PSS is Baytron Al 4083 from H.C.Starck, and filtered with a $0.45 \mu \mathrm{m}$ PES film before use. The thin layer of PEDOT:PSS was spin-coated on top of a cleaned ITO substrate at $3000 \mathrm{rpm} / \mathrm{s}$ for $60 \mathrm{~s}$ and dried subsequently at $130{ }^{\circ} \mathrm{C}$ for $15 \mathrm{~min}$ on a hotplate. The thickness of the PEDOT:PSS layer was about $40 \mathrm{~nm}$. The active layer was subsequently prepared by spin-coating the blend solution of small molecule and $\mathrm{PC}_{71} \mathrm{BM}$ on the top of ITO/PEDOT:PSS. The top electrode was thermally evaporated with a $0.6 \mathrm{~nm} \mathrm{LiF}$ layer, and followed by $100 \mathrm{~nm}$ of aluminum under a pressure of $10^{-4} \mathrm{~Pa}$ through a shadow mask. Five cells were fabricated on one substrate with an effective area of $0.04 \mathrm{~cm}^{2}$. The current-voltage $(I-V)$ curves of devices were completed by a computer-controlled Keithley 236 Source Measure Unit. An AM 1.5G AAA class solar simulator (model XES-301S, SAN-EI) in an intensity of $100 \mathrm{~mW} / \mathrm{cm}^{2}$ was used as the simulative sun light source, and the light intensity of the light was calibrated under a standard single-crystal Si photovoltaic cell.

\subsection{General Procedure for the Synthesis of Small Molecules}

The general procedure for the synthesis were shown in Scheme 1, A solution of BT or DPP, DFP or TPA, $\mathrm{K}_{2} \mathrm{CO}_{3}$, toluene $(50 \mathrm{~mL})$, and $\mathrm{H}_{2} \mathrm{O}(5 \mathrm{~mL})$ was carefully gas and degassed before and after $\mathrm{Pd}\left(\mathrm{PPh}_{3}\right)_{4}$ was added, and the mixture was stirring at $100{ }^{\circ} \mathrm{C}$ for two days. After the reaction, the mixture was poured into water $(100 \mathrm{~mL})$ and extracted with $\mathrm{CHCl}_{3}$. The organic layer was washed with water three times, and then dried by $\mathrm{MgSO}_{4}$. After evaporating to dryness, the pure product was obtained from column chromatography by a silica gel.

4,7-bis(5-(3,5-difluorophenyl)thiophen-2-yl)benzo[c][1,2,5]thiadiazole (DFP-BT-DFP): BT (0.96 g, $2.1 \mathrm{mmol})$, DFP (1.01 g, $4.2 \mathrm{mmol}), \mathrm{K}_{2} \mathrm{CO}_{3}(1.38 \mathrm{~g}, 10.0 \mathrm{mmol})$, and $\mathrm{Pd}\left(\mathrm{PPh}_{3}\right)_{4}(127.1 \mathrm{mg}, 0.11 \mathrm{mmol})$ were used. Yield: $0.73 \mathrm{~g}, 66 \%$ purple crystal. ${ }^{1} \mathrm{H}$ NMR $\left(400 \mathrm{MHz}, \mathrm{CDCl}_{3}\right) \delta .8 .12(\mathrm{~d}, 1 \mathrm{H}), 7.94(\mathrm{~s}, 1 \mathrm{H})$, $7.44(\mathrm{~d}, 1 \mathrm{H}) 7.52(\mathrm{~m}, 2 \mathrm{H}), 6.77(\mathrm{~m}, 1 \mathrm{H}) .{ }^{13} \mathrm{C} \mathrm{NMR}\left(100 \mathrm{MHz}, \mathrm{CDCl}_{3}\right)$ 8. 155.61, 151.55, 148.01, 143.27, 142.00, 137.55, 131.73, 120.63, 116.91. Analyze (Anal.) Calcd for $\mathrm{C}_{26} \mathrm{H}_{12} \mathrm{~F}_{4} \mathrm{~N}_{2} \mathrm{~S}_{3}: \mathrm{C}, 59.53 ; \mathrm{H}, 2.31 ; \mathrm{N}$, 5.34; Found: $\mathrm{C}, 59.42 ; \mathrm{H}, 2.40 ; \mathrm{N}, 5.26$. MALDI-TOF: calculated for $\mathrm{C}_{26} \mathrm{H}_{12} \mathrm{~F}_{4} \mathrm{~N}_{2} \mathrm{~S}_{3}$ 524.6, found 523.8.

4-(5-(7-(5-(3,5-difluorophenyl)thiophen-2-yl)benzo[c][1,2,5]thiadiazol-4-yl)thiophen-2-yl)-N,N-diphenylaniline (DFP-BT-TPA): BT (1.15 g, $2.5 \mathrm{mmol})$, DFP (0.60 g, $2.5 \mathrm{mmol})$, TPA $(0.93 \mathrm{~g}, 2.5 \mathrm{mmol}), \mathrm{K}_{2} \mathrm{CO}_{3}(1.38 \mathrm{~g}$, $10.0 \mathrm{mmol})$, and $\mathrm{Pd}\left(\mathrm{PPh}_{3}\right)_{4}(144.3 \mathrm{mg}, 0.11 \mathrm{mmol})$ were used. Yield: $0.67 \mathrm{~g}, 41 \%$ purple crystal. ${ }^{1} \mathrm{H}$ NMR $\left(400 \mathrm{MHz}, \mathrm{CDCl}_{3}\right)$ 8. $8.14(\mathrm{~d}, 1 \mathrm{H}), 8.08(\mathrm{~d}, 1 \mathrm{H}), 7.90(\mathrm{t}, 2 \mathrm{H}) 7.57(\mathrm{~d}, 2 \mathrm{H}), 7.43(\mathrm{~d}, 1 \mathrm{H}), 7.34(\mathrm{~d}$, 1H), $7.29(\mathrm{t}, 3 \mathrm{H}), 7.22(\mathrm{~d}, 2 \mathrm{H}), 7.16-7.00(\mathrm{~m}, 8 \mathrm{H}), 6.75(\mathrm{t}, 1 \mathrm{H}) .{ }^{13} \mathrm{C} \mathrm{NMR}\left(100 \mathrm{MHz}, \mathrm{CDCl}_{3}\right)$ 8. 161.66, 158.56, 153.96, 145.33, 143.04, 139.03, 132.72, 129.49, 127.99, 124.80, 123.41, 123.32, 115.51. Anal. Calcd for $\mathrm{C}_{38} \mathrm{H}_{23} \mathrm{~F}_{2} \mathrm{~N}_{3} \mathrm{~S}_{3}$ : C, 69.60; H, 3.54; N, 6.41 Found: C, 69.45; H, 3.52; N, 6.40. MALDI-TOF: calculated for $\mathrm{C}_{38} \mathrm{H}_{23} \mathrm{~F}_{2} \mathrm{~N}_{3} \mathrm{~S}_{3} 655.8$, found 654.9 .

4,4'-(5,5'-(benzo[c][1,2,5]thiadiazole-4,7-diyl)bis(thiophene-5,2-diyl))bis(,$N$-diphenylaniline) (TPA-BT-TPA): BT (1.01 g, $2.2 \mathrm{mmol})$, TPA (1.63 g, $4.4 \mathrm{mmol}), \mathrm{K}_{2} \mathrm{CO}_{3}(1.22 \mathrm{~g}, 8.8 \mathrm{mmol})$, and $\mathrm{Pd}\left(\mathrm{PPh}_{3}\right)_{4}(127.1 \mathrm{mg}$, $0.11 \mathrm{mmol})$ were used. Yield: $1.30 \mathrm{~g}, 75 \%$ purple crystal. ${ }^{1} \mathrm{H} \mathrm{NMR}\left(400 \mathrm{MHz}, \mathrm{CDCl}_{3}\right) \delta .8 .11(\mathrm{~s}, 2 \mathrm{H})$, $7.85(\mathrm{~s}, 2 \mathrm{H}), 7.56(\mathrm{~m}, 4 \mathrm{H}), 7.29(\mathrm{~m}, 10 \mathrm{H}), 7.08(\mathrm{~m}, 16 \mathrm{H}) .{ }^{13} \mathrm{C} \mathrm{NMR}\left(100 \mathrm{MHz}, \mathrm{CDCl}_{3}\right)$ ). 152.57, 147.58, $147.39,129.35,128.67,128.03,126.60,125.61,125.14,124.64,123.46,123.23$. Anal. Calcd for $\mathrm{C}_{50} \mathrm{H}_{34} \mathrm{~N}_{4} \mathrm{~S}_{3}$ : C, 76.30; $\mathrm{H}, 4.35 ; \mathrm{N}, 7.12$. Found: $\mathrm{C}, 76.17 ; \mathrm{H}, 4.36 ; \mathrm{N}, 7.02$. MALDI-TOF: calculated for $\mathrm{C}_{50} \mathrm{H}_{34} \mathrm{~N}_{4} \mathrm{~S}_{3}$ 787.0, found 785.9. 
3,6-bis(5-(3,5-difluorophenyl)thiophen-2-yl)-2,5-dioctylpyrrolo[3,4-c]pyrrole-1,4(2H,5H)-dione(DFP-DPP-DFP): DPP (1.37 g, $2.0 \mathrm{mmol})$ and DFP $(0.96 \mathrm{~g}, 4.0 \mathrm{mmol}), \mathrm{K}_{2} \mathrm{CO}_{3}(1.11 \mathrm{~g}, 8.0 \mathrm{mmol})$, and $\mathrm{Pd}\left(\mathrm{PPh}_{3}\right)_{4}(115.5 \mathrm{mg}$, $0.11 \mathrm{mmol})$ were used. Yield: $0.91 \mathrm{~g}, 66 \%$ gray solid. ${ }^{1} \mathrm{H} \mathrm{NMR}\left(400 \mathrm{MHz}, \mathrm{CDCl}_{3}\right) \delta .8 .94(\mathrm{~d}, 2 \mathrm{H}), 7.48$ $(\mathrm{d}, 2 \mathrm{H}), 7.19(\mathrm{~d}, 4 \mathrm{H}), 6.82(\mathrm{t}, 2 \mathrm{H}), 4.11(\mathrm{t}, 4 \mathrm{H}), 1.77(\mathrm{t}, 4 \mathrm{H}), 1.46-1.28(\mathrm{~m}, 20 \mathrm{H}), 0.86(\mathrm{t}, 6 \mathrm{H}){ }^{13} \mathrm{C}$ NMR $(100$ $\mathrm{MHz}, \mathrm{CDCl}_{3}$ ) $\delta .161 .26,155.77,155.15,149.36,146.58,139.32,136.46,129.90,125.89,109.15,108.85$, 42.32, 31.79, 30.01, 29.28, 29.21, 26.90, 22.63, 14.07. Anal. Calcd for $\mathrm{C}_{42} \mathrm{H}_{44} \mathrm{~F}_{4} \mathrm{~N}_{2} \mathrm{O}_{2} \mathrm{~S}_{2}: \mathrm{C}, 67.36 ; \mathrm{H}, 5.92$; $\mathrm{N}$, 3.74. Found: $\mathrm{C}, 67.12 ; \mathrm{H}, 5.92 ; \mathrm{N}, 3.73$. MALDI-TOF: calculated for $\mathrm{C}_{42} \mathrm{H}_{44} \mathrm{~F}_{4} \mathrm{~N}_{2} \mathrm{O}_{2} \mathrm{~S}_{2}$ 748.9, found 748.1.

3-(5-(3,5-difluorophenyl)thiophen-2-yl)-6-(5-(4-(diphenylamino)phenyl)thiophen-2-yl)-2,5-dioctylpyrrolo pyrrole-1,4(2H,5H)-dione(DFP-DPP-TPA): DPP (1.91 g, $2.8 \mathrm{mmol})$, DFP $(0.67 \mathrm{~g}, 2.8 \mathrm{mmol})$ and TPA $(1.04 \mathrm{~g}, 2.8 \mathrm{mmol}), \mathrm{K}_{2} \mathrm{CO}_{3}(3.33 \mathrm{~g}, 14.0 \mathrm{mmol})$, and $\mathrm{Pd}\left(\mathrm{PPh}_{3}\right)_{4}(161.7 \mathrm{mg}, 0.14 \mathrm{mmol})$ were used. Yield: $0.76 \mathrm{~g}, 31 \%$ gray solid. ${ }^{1} \mathrm{H}$ NMR $\left(400 \mathrm{MHz}, \mathrm{CDCl}_{3}\right) \delta .9 .04(\mathrm{~s}, 1 \mathrm{H}), 8.87(\mathrm{~s}, 1 \mathrm{H}), 7.52(\mathrm{~s}, 2 \mathrm{H}), 7.44(\mathrm{~s}, 1 \mathrm{H})$, $7.36(\mathrm{~s}, 1 \mathrm{H}), 7.30(\mathrm{t}, 4 \mathrm{H}), 7.14(\mathrm{~d}, 6 \mathrm{H}), 7.08(\mathrm{dd}, 4 \mathrm{H}), 6.78(\mathrm{~s}, 1 \mathrm{H}), 4.09(\mathrm{t}, 4 \mathrm{H}), 1.76(\mathrm{t}, 4 \mathrm{H}), 1.45-1.26(\mathrm{~m}$, 20H), $0.85(\mathrm{t}, 6 \mathrm{H}) .{ }^{13} \mathrm{C}$ NMR $\left(100 \mathrm{MHz}, \mathrm{CDCl}_{3}\right) \delta .148 .74,147.02,137.71,129.47,126.99,126.30,125.09$, 123.80, 123.64, 122.58, 109.05, 108.77, 42.32, 31.82, 30.04, 29.27, 29.22, 26.94, 22.64, 14.12. Anal. Calcd for $\mathrm{C}_{55} \mathrm{H}_{59} \mathrm{~F}_{2} \mathrm{~N}_{3} \mathrm{O}_{2} \mathrm{~S}_{2}$ : $\mathrm{C}, 73.71 ; \mathrm{H}, 6.64 ; \mathrm{N}, 4.69$. Found: $\mathrm{C}, 73.25 ; \mathrm{H}, 6.35 ; \mathrm{N}, 4.73$. MALDI-TOF: calculated for $\mathrm{C}_{55} \mathrm{H}_{59} \mathrm{~F}_{2} \mathrm{~N}_{3} \mathrm{O}_{2} \mathrm{~S}_{2}$ 896.2, found 895.3.

3,6-bis(5-(4-(diphenylamino)phenyl)thiophen-2-yl)-2,5-dioctylpyrrolo[3,4-c]pyrrole-1,4(2H,5H)-dione (TPA-DPP-TPA): DPP (1.30 g, $1.9 \mathrm{mmol})$ and TPA (1.41 g, $3.8 \mathrm{mmol}), \mathrm{K}_{2} \mathrm{CO}_{3}(1.31 \mathrm{~g}, 9.5 \mathrm{mmol})$, and $\mathrm{Pd}\left(\mathrm{PPh}_{3}\right)_{4}(115.5 \mathrm{mg}, 0.10 \mathrm{mmol})$ were used. Yield: $1.35 \mathrm{~g}, 70 \%$ gray solid. ${ }^{1} \mathrm{H} \mathrm{NMR}\left(400 \mathrm{MHz}, \mathrm{CDCl}_{3}\right)$

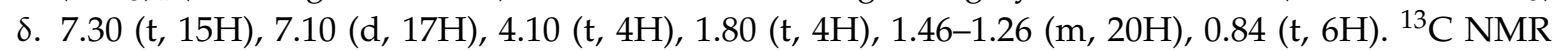

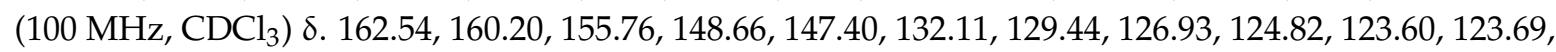
$122.72,110.77,42.28,31.81,30.03,29.24,29.22,26.93,22.63,14.10$. Anal. Calcd for $\mathrm{C}_{66} \mathrm{H}_{66} \mathrm{~N}_{4} \mathrm{O}_{2} \mathrm{~S}_{2}: \mathrm{C}$, 78.38; $\mathrm{H}, 6.58 ; \mathrm{N}, 5.54$. Found: $\mathrm{C}, 78.17 ; \mathrm{H}, 6.61 ; \mathrm{N}, 5.38$. MALDI-TOF: calculated for $\mathrm{C}_{66} \mathrm{H}_{66} \mathrm{~N}_{4} \mathrm{O}_{2} \mathrm{~S}_{2}$ 1011.4, found 1010.1.

\section{Conclusions}

In conclusion, six small molecules (DFP-BT-DFP, DFP-BT-TPA, TPA-BT-TPA, DFP-DPP-DFP, DFP-DPP-TPA, and TPA-DPP-TPA) based on 2,1,3-benzothiadiazole (BT) or diketopyrrolopyrrole (DPP) as the core and TPA or fluorinated phenyl (DFP) as the end groups were designed and synthesized as the donors in OSCs. To investigate the influence of fluorinated donor unit on the photovoltaic performance of devices, various DFP groups were conjugated. With one or two DFP as the end group(s), HOMO level of TPA-BT-TPA, DFP-BT-TPA, and DFP-BT-DFP was gradually decreased; similar tendency could also be observed for DPP based small molecular donors, inducing high $V_{\text {oc }}$ for DFP based OSCs. DFP-BT-TPA and DFP-DPP-TPA based blend films both displayed stronger nano-scale aggregation in comparison to TPA-BT-TPA and TPA-DPP-TPA, respectively, which would also lead to higher hole motilities in devices. Ultimately, a PCE of $2.17 \%$ with a $V_{\mathrm{oc}}$ of $0.90 \mathrm{~V}$ was acquired for DFP-BT-TPA based devices. Our results demonstrated that the nano-scale aggregation size of small molecules in photovoltaic devices could be significantly enhanced by introducing a fluorine atom at the donor unit of small molecules. Although the PCE is not attractive enough, this work will provide understanding about the relationship of chemical structure and nano-scale phase separation in OSCs.

Supplementary Materials: The following are available online at http://www.mdpi.com/2079-4991/6/4/80/s1. Acknowledgments: Financial support from PhD Research Startup Foundation of Shanxi Datong University (2013-B-01), School foundation of Shanxi Datong University (XDC2014110), the NSF of China (91233205), the NSF of China (51403021), the NSF of China (21375083) and Beijing Natural Science Foundation (2152017).

Author Contributions: The experimental design was planned by Feng Feng and Wenhua Li. The experimental work and data analysis were performed by Zhen Lu, Wen Liu, Jingjing Li, Tao Fang, Wannin Li and Jicheng Zhang.

Conflicts of Interest: The authors declare no conflict of interest. 


\section{References}

1. Liang, Y.; Xu, Z.; Xia, J.; Tsai, S.-T.; Wu, Y.; Li, G.; Ray, C.; Yu, L. For the Bright Future-Bulk Heterojunction Polymer Solar Cells with Power Conversion Efficiency of 7.4\%. Adv. Mater. 2010, 22, E135-E138. [CrossRef] [PubMed]

2. Lu, L.; Zheng, T.; Wu, Q.; Schneider, A.M.; Zhao, D.; Yu, L. Recent Advances in Bulk Heterojunction Polymer Solar Cells. Chem. Rev. 2015, 115, 12666-12731. [CrossRef] [PubMed]

3. Chen, J.; Cao, Y. Development of Novel Conjugated Donor Polymers for High-Efficiency Bulk-Heterojunction Photovoltaic Devices. Acc. Chem. Res. 2009, 42, 1709-1718. [CrossRef] [PubMed]

4. Li, Y. Molecular Design of Photovoltaic Materials for Polymer Solar Cells: Toward Suitable Electronic Energy Levels and Broad Absorption. Acc. Chem. Res. 2012, 45, 723-733. [CrossRef] [PubMed]

5. Lin, Y.; Li, Y.; Zhan, X. Small molecule semiconductors for high-efficiency organic photovoltaics. Chem. Soc. Rev. 2012, 41, 4245-4272. [CrossRef] [PubMed]

6. Cui, C.; Guo, X.; Min, J.; Guo, B.; Cheng, X.; Zhang, M.; Brabec, C.J.; Li, Y. High-Performance Organic Solar Cells Based on a Small Molecule with Alkylthio-Thienyl-Conjugated Side Chains without Extra Treatments. Adv. Mater. (Deerfield Beach Fla.) 2015, 27, 7469-7475. [CrossRef] [PubMed]

7. Liu, C.; Yi, C.; Wang, K.; Yang, Y.L.; Bhatta, R.S.; Tsige, M.; Xiao, S.Y.; Gong, X. Single-Junction Polymer Solar Cells with Over 10\% Efficiency by a Novel Two-Dimensional Donor-Acceptor Conjugated Copolymer. ACS Appl. Mater. Interfaces 2015, 7, 4928-4935. [CrossRef] [PubMed]

8. Shang, H.; Fan, H.; Liu, Y.; Hu, W.; Li, Y.; Zhan, X. A Solution-Processable Star-Shaped Molecule for High-Performance Organic Solar Cells. Adv. Mater. 2011, 23, 1554-1557. [CrossRef] [PubMed]

9. Sun, Y.; Welch, G.C.; Leong, W.L.; Takacs, C.J.; Bazan, G.C.; Heeger, A.J. Solution-processed small-molecule solar cells with 6.7\% efficiency. Nat. Mater. 2012, 11, 44-48. [CrossRef] [PubMed]

10. Zhang, Q.; Kan, B.; Liu, F.; Long, G.; Wan, X.; Chen, X.; Zuo, Y.; Ni, W.; Zhang, H.; Li, M.; et al. Small-molecule solar cells with efficiency over 9\%. Nat. Photonics 2015, 9, 35-41. [CrossRef]

11. Kan, B.; Zhang, Q.; Li, M.; Wan, X.; Ni, W.; Long, G.; Wang, Y.; Yang, X.; Feng, H.; Chen, Y. Solution-Processed Organic Solar Cells Based on Dialkylthiol-Substituted Benzodithiophene Unit with Efficiency near 10\%. J. Am. Chem. Soc. 2014, 136, 15529-15532. [CrossRef] [PubMed]

12. Ni, W.; Li, M.; Kan, B.; Zuo, Y.; Zhang, Q.; Long, G.; Feng, H.; Wan, X.; Chen, Y. Open-circuit voltage up to $1.07 \mathrm{~V}$ for solution processed small molecule based organic solar cells. Organic Electron. 2014, 15, 2285-2294. [CrossRef]

13. Carsten, B.; Szarko, J.M.; Son, H.J.; Wang, W.; Lu, L.; He, F.; Rolczynski, B.S.; Lou, S.J.; Chen, L.X.; Yu, L. Examining the Effect of the Dipole Moment on Charge Separation in Donor-Acceptor Polymers for Organic Photovoltaic Applications. J. Am. Chem. Soc. 2011, 133, 20468-20475. [CrossRef] [PubMed]

14. Chen, H.Z.; Ling, M.M.; Mo, X.; Shi, M.M.; Wang, M.; Bao, Z. Air stable $n$-channel organic semiconductors for thin film transistors based on fluorinated derivatives of perylene diimides. Chem. Mater. 2007, 19, 816-824. [CrossRef]

15. Li, K.; Li, Z.; Feng, K.; Xu, X.; Wang, L.; Peng, Q. Development of Large Band-Gap Conjugated Copolymers for Efficient Regular Single and Tandem Organic Solar Cells. J. Am. Chem. Soc. 2013, 135, 13549-13557. [CrossRef] [PubMed]

16. Schroeder, B.C.; Huang, Z.; Ashraf, R.S.; Smith, J.; D’Angelo, P.; Watkins, S.E.; Anthopoulos, T.D.; Durrant, J.R.; McCulloch, I. Silaindacenodithiophene-Based Low Band Gap Polymers-The Effect of Fluorine Substitution on Device Performances and Film Morphologies. Adv. Funct. Mater. 2012, 22, 1663-1670. [CrossRef]

17. Shewmon, N.T.; Watkins, D.L.; Galindo, J.F.; Zerdan, R.B.; Chen, J.; Keum, J.; Roitberg, A.E.; Xue, J.; Castellano, R.K. Enhancement in Organic Photovoltaic Efficiency through the Synergistic Interplay of Molecular Donor Hydrogen Bonding and $\pi$-Stacking. Adv. Funct. Mater. 2015, 25, 5166-5177. [CrossRef]

18. Wang, L.; Yin, L.; Ji, C.; Li, Y. Tuning the photovoltaic performance of BT-TPA chromophore based solution-processed solar cells through molecular design incorporating of bithiophene unit and fluorine-substitution. Dyes Pigments 2015, 118, 37-44. [CrossRef]

19. Sonar, P.; Ng, G.-M.; Lin, T.T.; Dodabalapur, A.; Chen, Z.-K. Solution processable low bandgap diketopyrrolopyrrole (DPP) based derivatives: Novel acceptors for organic solar cells. J. Mater. Chem. 2010, 20, 3626-3636. [CrossRef] 
20. Cui, R.; Fan, L.; Yuan, J.; Jiang, L.; Chen, G.; Ding, Y.; Shen, P.; Li, Y.; Zou, Y. Effect of fluorination on the performance of poly(thieno[2,3-f]benzofuran-co-benzothiadiazole) derivatives. RSC Adv. 2015, 5, 30145-30152. [CrossRef]

21. Guo, S.; Ning, J.; Koerstgens, V.; Yao, Y.; Herzig, E.M.; Roth, S.V.; Mueller-Buschbaum, P. The Effect of Fluorination in Manipulating the Nanomorphology in PTB7:PC 71 BM Bulk Heterojunction Systems. Adv. Energy Mater. 2015, 5. [CrossRef]

22. Jo, J.W.; Jung, J.W.; Jung, E.H.; Ahn, H.; Shin, T.J.; Jo, W.H. Fluorination on both D and A units in D-A type conjugated copolymers based on difluorobithiophene and benzothiadiazole for highly efficient polymer solar cells. Energy Environ. Sci. 2015, 8, 2427-2434. [CrossRef]

23. Kim, H.G.; Kang, B.; Ko, H.; Lee, J.; Shin, J.; Cho, K. Synthetic Tailoring of Solid-State Order in Diketopyrrolopyrrole-Based Copolymers via Intramolecular Noncovalent Interactions. Chem. Mater. 2015, 27, 829-838. [CrossRef]

24. Wang, J.-L.; Wu, Z.; Miao, J.-S.; Liu, K.-K.; Chang, Z.-F.; Zhang, R.-B.; Wu, H.-B.; Cao, Y. Solution-Processed Diketopyrrolopyrrole-Containing Small-Molecule Organic Solar Cells with 7.0\% Efficiency: In-Depth Investigation on the Effects of Structure Modification and Solvent Vapor Annealing. Chem. Mater. 2015, 27, 4338-4348. [CrossRef]

25. Cho, A.; Kim, Y.; Song, C.E.; Moon, S.-J.; Lim, E. Synthesis and Characterization of Fluorinated Benzothiadiazole-Based Small Molecules for Organic Solar Cells. Sci. Adv. Mater. 2014, 6, 2411-2415. [CrossRef]

26. Paek, S.; Cho, N.; Song, K.; Jun, M.J.; Lee, J.K.; Ko, J. Efficient Organic Semiconductors Containing Fluorine-Substituted Benzothiadiazole for Solution-Processed Small Molecule Organic Solar Cells. J. Phys. Chem. C 2012, 116, 23205-23213. [CrossRef]

27. Cho, N.; Song, K.; Lee, J.K.; Ko, J. Facile Synthesis of Fluorine-Substituted Benzothiadiazole-Based Organic Semiconductors and Their Use in Solution-Processed Small-Molecule Organic Solar Cells. Chem. Eur. J. 2012, 18, 11433-11439. [CrossRef] [PubMed]

28. Dutta, P.; Yang, W.; Eom, S.H.; Lee, S.-H. Synthesis and characterization of triphenylamine flanked thiazole-based small molecules for high performance solution processed organic solar cells. Organic Electron. 2012, 13, 273-282. [CrossRef]

29. Li, Z.; Dong, Q.; Li, Y.; Xu, B.; Deng, M.; Pei, J.; Zhang, J.; Chen, F.; Wen, S.; Gao, Y.; Tian, W. Design and synthesis of solution processable small molecules towards high photovoltaic performance. J. Mater. Chem. 2011, 21, 2159-2168. [CrossRef]

30. Lin, Y.; Cheng, P.; Li, Y.; Zhan, X. A 3D star-shaped non-fullerene acceptor for solution-processed organic solar cells with a high open-circuit voltage of 1.18 V. Chem. Commun. 2012, 48, 4773-4775. [CrossRef] [PubMed]

31. Vijay Kumar, C.; Cabau, L.; Koukaras, E.N.; Sharma, G.D.; Palomares, E. Efficient solution processed $\mathrm{D}_{1}-\mathrm{A}-\mathrm{D}_{2}-\mathrm{A}-\mathrm{D}_{1}$ small molecules bulk heterojunction solar cells based on alkoxy triphenylamine and benzo[1,2-b:4,5-b']thiophene units. Organic Electron. 2015, 26, 36-47. [CrossRef]

32. Patil, H.; Chang, J.; Gupta, A.; Bilic, A.; Wu, J.; Sonar, P.; Bhosale, S.V. Isoindigo-Based Small Molecules with Varied Donor Components for Solution-Processable Organic Field Effect Transistor Devices. Molecules 2015, 20, 17362-17377. [CrossRef] [PubMed]

33. Bagde, S.S.; Park, H.; Yang, S.-N.; Jin, S.-H.; Lee, S.-H. Diketopyrrolopyrrole-based narrow band gap donors for efficient solution-processed organic solar cells. Chem. Phys. Lett. 2015, 630, 37-43. [CrossRef]

34. Mikroyannidis, J.A.; Stylianakis, M.M.; Suresh, P.; Balraju, P.; Sharma, G.D. Low band gap vinylene compounds with triphenylamine and benzothiadiazole segments for use in photovoltaic cells. Organic Electron. 2009, 10, 1320-1333. [CrossRef]

35. Tolman, C.A.; Seidel, W.C.; Gerlach, D.H. Triarylphosphine and ethylene complexes of zerovalent nickel, palladium, and platinum. J. Am. Chem. Soc. 1972, 94, 2669-2676. [CrossRef]

36. Kato, S.-I.; Matsumoto, T.; Ishi-i, T.; Thiemann, T.; Shigeiwa, M.; Gorohmaru, H.; Maeda, S.; Yamashita, Y.; Mataka, S. Strongly red-fluorescent novel donor- $\pi$-bridge-acceptor- $\pi$-bridge-donor (D- $\pi$-A- $\pi$-D) type 2,1,3-benzothiadiazoles with enhanced two-photon absorption cross-sections. Chem. Commun. 2004, 20, 2342-2343. [CrossRef] [PubMed]

37. Zou, Y.; Gendron, D.; Badrou-Aïch, R.; Najari, A.; Tao, Y.; Leclerc, M. A High-Mobility Low-Bandgap Poly(2,7-carbazole) Derivative for Photovoltaic Applications. Macromolecules 2009, 42, 2891-2894. [CrossRef] 
38. Huang, J.; Zhan, C.; Zhang, X.; Zhao, Y.; Lu, Z.; Jia, H.; Jiang, B.; Ye, J.; Zhang, S.; Tang, A.; et al. Solution-Processed DPP-Based Small Molecule that Gives High Photovoltaic Efficiency with Judicious Device Optimization. ACS Appl. Mater. Interfaces 2013, 5, 2033-2039. [CrossRef] [PubMed]

39. Uhrich, C.; Schueppel, R.; Petrich, A.; Pfeiffer, M.; Leo, K.; Brier, E.; Kilickiran, P.; Baeuerle, P. Organic Thin-Film Photovoltaic Cells Based on Oligothiophenes with Reduced Bandgap. Adv. Funct. Mater. 2007, 17, 2991-2999. [CrossRef]

40. Lu, Z.; Li, C.-H.; Du, C.; Gong, X.; Bo, Z.-S. 6,7-dialkoxy-2,3-diphenylquinoxaline based conjugated polymers for solar cells with high open-circuit voltage. Chin. J. Polym. Sci. 2013, 31, 901-911. [CrossRef]

41. Shang, Y.; Hao, S.; Liu, J.; Tan, M.; Wang, N.; Yang, C.; Chen, G. Synthesis of Upconversion beta- $\mathrm{NaYF}_{4}: \mathrm{Nd}^{3+} / \mathrm{Yb}^{3+} / \mathrm{Er}^{3+}$ Particles with Enhanced Luminescent Intensity through Control of Morphology and Phase. Nanomaterials 2015, 5, 218-232. [CrossRef]

(C) 2016 by the authors; licensee MDPI, Basel, Switzerland. This article is an open access article distributed under the terms and conditions of the Creative Commons Attribution (CC-BY) license (http://creativecommons.org/licenses/by/4.0/). 